\title{
Short communication: \\ The preference and functional response of Sycanus aurantiacus (Hemiptera: Heteroptera: Reduviidae) on three prey types in laboratory conditions
}

\author{
KETUT AYU YULIADHI ${ }^{1, \vartheta}$, I WAYAN SUPARTHA ${ }^{1, \bullet \bullet}$, I NYOMAN WIJAYA ${ }^{2}$, PUDJIANTO ${ }^{3}$, \\ ALI NURMANSYAH ${ }^{3}$, I WAYAN SUSILA ${ }^{1}$, I KADEK WISMA YUDHA ${ }^{4}$, I WAYAN EKA KARYA UTAMA ${ }^{4}$, \\ PUTU ANGGA WIRADANA ${ }^{5}$ \\ ${ }^{1}$ Integrated Pest Laboratory, Faculty of Agriculture, Universitas Udayana. Jl. P.B. Sudirman, Denpasar 80234, Bali, Indonesia. \\ Tel./fax.: +62-361-701907, `email:ayususrusa@yahoo.co.id; ‘vyansupartha@yahoo.com \\ ${ }^{2}$ Program of Agroecotechnology, Faculty of Agriculture, Universitas Udayana. Jl. P.B. Sudirman, Denpasar 80234, Bali, Indonesia \\ ${ }^{3}$ Department of Plant Protection, Faculty of Agriculture, Institut Pertanian Bogor. Jl. Meranti, Dramaga, Bogor 16680, West Java, Indonesia \\ ${ }^{4}$ Doctoral Program of Agricultural Science, Faculty of Agriculture, Universitas Udayana, J1. P.B. Sudirman, Denpasar 80234, Bali, Indonesia \\ ${ }^{5}$ Program of Biology, Faculty of Health, Science and Technology, Universitas Dhyana Pura. Jl. Raya Padang Luwih, Badung 80361, Bali, Indonesia
}

Manuscript received: 24 October 2021. Revision accepted: 29 November 2021.

\begin{abstract}
Yuliadhi KA, Supartha IW, Wijaya IN, Pudjianto, Nurmansyah A, Susila IW, Yudha IKW, Utama IWEK, Wiradana PA. 2021. Short communication: The preference and functional response of Sycanus aurantiacus (Hemiptera: Heteroptera: Reduviidae) on three prey types in laboratory conditions. Biodiversitas 22: 5662-5667. Sycanus aurantiacus Ishikawa et Okajima (Hemiptera: Heteroptera) is a valuable predatory insect that can be cultivated in biological pest control programs, particularly in vegetable crops. The research aimed to investigate the preferences and functional responses of the predator Sycanus aurantiacus to three different prey species in the laboratory conditions, included Plutella xylostella (Linnaeus), Crocidolomia pavonana (Fabricius), and Tenebrio molitor (Linnaeus). The preference experiment was carried out by monitoring the prey on which $S$. aurantiacus preyed the most. The functional responsiveness of $S$. aurantiacus was determined by measuring the time it took to detect and prey on various kinds of prey, as well as the number of prey that were successfully preyed upon when the quantity of prey was increased. The predatory $S$. aurantiacus preferred P. xylostella over C. pavonana and T. molitor. S. aurantiacus functional response to three kinds of prey, including type II, is shown. In P. xylostella, the instantaneous prey search rate (a) was $0.2 /$ hour, with a handling time (Th) of 1 hour 40 minutes/prey, which was quicker than the other two kinds of prey. As a result of our findings, the predator S. aurantiacus can be maintained in the lab and has the potential to be developed as an efficient biocontrol agent, particularly against the cabbage leaf caterpillar $P$. xylostella.
\end{abstract}

Keywords: Biological control, feeding behavior, insect predator, Reduviidae, Sycanus aurantiacus

\section{INTRODUCTION}

Cabbage (Brassica oleracea L. var. capitate) is one of the most significant vegetable commodities grown by vegetable growers in Bali Province, Indonesia, alongside tomatoes and carrots. However, pests and diseases often disrupt cabbage growing operations. According to the study, cabbage productions in Bali Province varied between 2018 and 2020 (Anon 2020). Several insect pests reported attacking cabbage crops include the cabbage leaf caterpillar, Plutella xylostella (Prabaningrum and Moekasan 2021), the cabbage heart caterpillar, Crocidolomia pavonana (Uelese et al. 2014), armyworm, Spodoptera litura Fab. (Chen et al. 2021), earthworm, Agrotis ipsilon Hufnagel. (Rameash et al. 2014), Chrysodeixis orichalcea L. (Kumarawati et al. 2013), Helicoverpa armigera (Hubner) (Rabari et al. 2017), Hellula undalis Fab. (Hoa and Giang 2019), and the Hongkong caterpillar, Tenebrio molitor (Yuliadhi 2012).

Among the bug species identified, three are significant pests in cabbage production in Indonesia: P. xylostella, $C$. pavonana, and T. molitor. Pests of $P$. xylostella usually cause harm to cabbage plants before they produce plants by consuming the lower surface tissue of the leaves and leaving the top surface epidermis intact. $C$. pavonana attacks plants, causing cauliflower leaves to perforate and, when attacked at the growth stage, plant death. T. molitor is both a coleopteran model insect and a significant agricultural pest in the Tenebrionidae family (Kim et al. 2018; Zhiganov et al. 2021).

Integrated pest management using biological resources such as natural enemies is one of the control ideas based on ecological and economic methods (Supartha et al. 2020). Furthermore, the employment of natural enemies as a pest control agent is intimately connected to sustainable agriculture principles (Hatt et al. 2017). Predators are natural competitors with the potential to be utilized as biological control agents (Bordini et al. 2021). The employment of predators in the field has been shown to reduce pest populations by preserving the stability of pest population density and the food chain in the field (Yuliadhi et al. 2021). The functional response of a predator can 
provide an overview of the relationship between the amount of prey consumed per unit of time and the abundance or density of prey. This is a classic concept related to predation ability and is very important to be used in several research fields, such as behavioral, physiological, and evolutionary ecology, because functional responses and related models can be key elements of ecology in determining prey species (Jeschke et al. 2021). Holling (1959) has described three types of functional responses, including type $\mathrm{I}$, where there is a linear relationship between prey density and the maximum number of prey killed; type II, which explains that the proportion of prey consumed decreases monotonically with prey density; and type III, describes a sigmoid relationship in which the proportion of prey consumed is positively dependent on density in some areas of prey density. Determination of functional response is considered important in evaluating handling time and attack rate or search efficiency. Previous reports have stated that many types of predators have been released on a field scale as biocontrol agents that show a type II response to their prey (Xiao et al. 2013).

However, in their development, biocontrol agents' functional response experiments are limited to experimental patches applied to one prey type, whereas in nature, they freely attack a wide range of prey types (Fathipour and Maleknia 2016). It is very important to test potential predators on several different types of prey. Members of the heteropteran family Reduviidae, often known as "Assassin Bugs" are predatory insects that prey on most other insect species (Walker et al. 2018). To date, 23 Reduviidae subfamilies have been identified (Berenger and Parola 2017). This demonstrates that the Reduviidae are an essential family that should be maintained during mass laboratory maintenance in order to have a future effect on Integrated Pest Management (IPM) (Ambrose and Ganesh 2016). Sycanus aurantiacus, which was described from a cabbage plantation in Pancasari Village, Buleleng, Bali, and is currently predating some Lepidoptera larvae of cabbage pests, is one species of the Reduviidae family that has the potential to be used as a pest biocontrol agent (Ishikawa et al. 2007). Furthermore, another species of predator, Sycanus dichotomus, and one type of parasitoid, Diadegma semiclausum Hellen (Hemynoptera: Ichneumonidae), were discovered in a 2011 survey on cabbage plantings in the same area (Yuliadhi 2012). Furthermore, Sycanus collaris is known to have an important record in controlling pests on the teak and can also give preference to predators in the field after feeding (Poopat and Maneerat 2021).

Based on this, the aim of the research is to evaluate the impact of $S$. aurantiacus as a predator on three different kinds of prey, namely $P$. xylostella, C. pavonana, and $T$. molitor, on a laboratory scale. It is anticipated that our results will offer detailed information on the interactions between $S$. aurantiacus and the third prey species, allowing it to be developed as a possible biological agent in the future.

\section{MATERIALS AND METHOD}

\section{Study area}

Surveys and laboratory-scale experiments were used in the study. The study was carried out in a cabbage plantation in Pancasari Village, Buleleng, Bali, Indonesia. Field temperature and relative humidity were measured by using UNI-T UT333 Thermometer Hygrometer Humidity $\left(25^{\circ} \mathrm{C}\right.$ and $70-80 \%$, respectively). Experiments were performed out at the Integrated Pest Management Laboratory (IPMLab) at Udayana University's Faculty of Agriculture. The laboratory conditions used for the experiment were set at $24^{\circ} \mathrm{C}$ and $64 \%$ humidity.

\section{Predator Sycanus aurantiacus}

The predator $S$. aurantiacus was collected from a 300 $\mathrm{m}^{2}$ cabbage crop in Pancasari Village, Buleleng. $S$. arisanus (Figure 1) was identified by using Ishikawa et al. (2007). A total of 11 adults (4 males and 7 females) of $S$. aurantiacus were maintained in a plastic box $35 \mathrm{~cm}$ in length, $27 \mathrm{~cm}$ broad, and $7 \mathrm{~cm}$ high. The adults demonstrated the ability to lay eggs, which developed into nymphs to generate new adults, which were utilized as test insects in this research.

\section{Predatory preference of Sycanus aurantiacus towards three types of prey}

On a laboratory scale, predatory $S$. aurantiacus was studied for predation preferences on three different types of prey, namely $P$. xylostella, C. pavonana, and $T$. molitor. Considering that the three kinds of prey vary in behavior and appearance, a Completely Randomized Design (CRD) with 10 replications was employed in the preference experiment. This experiment was carried out using a predator that was given three different kinds of prey to test, each containing up to 10 individuals. Predators fasted for 12 hours before the preference test with the aim that when treated, the predator can directly prey on the provided larvae (Efendi et al. 2016). The quantity of prey consumed and remaining was recorded, and the percentage of prey remaining was determined for each prey species.

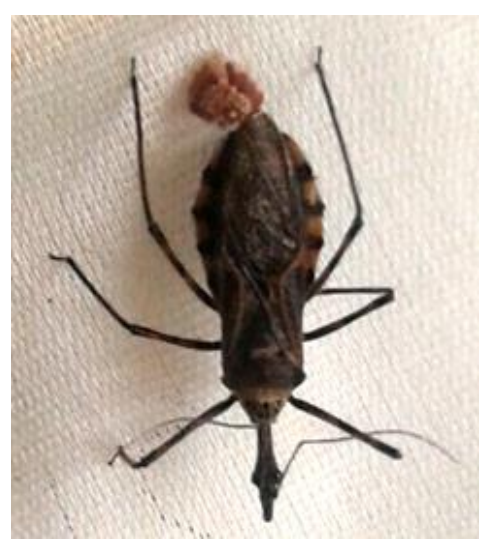

Figure 1. Sycanus aurantiacus laying eggs 
Preference for the kind of prey species is calculated using Manly (1974) preference index and the equation:

$$
a_{i}=\frac{\log p_{i}}{\log \left(p_{i}\right)+\log \left(p_{j}\right)}
$$

With $\alpha_{\mathrm{i}}$ express preference to prey species $\mathrm{i}, p_{i}$ and $p_{j}$ successively states the proportion of prey species $i$ and $j$ the remaining prey at the end of the experiment. Preference index $\alpha_{\mathrm{i}}$ Preference index 0 to 1 , with a value higher or closer to 1 indicates a higher level of preference. Preference index calculation is done with Ms Excel 2019 Software (Microsoft, USA).

\section{The functional response of predatory Sycanus aurantiacus to the three types of prey}

Examinations were made by assessing the time required $S$. aurantiacus to discover and prey and the quantity of prey it took by increasing the number of prey. The predatory functional response function experiment was carried out by assessing two key parameters that define the role of predators in reducing the growth of pest populations. The two parameters are the instantaneous prey search rate or attack rate (a) and prey handling time per predator (b) (Th). The two parameters' values are estimated in two stages: model selection and parameter estimation (Dunn and Hovel 2020).

Because the functional response curves of type II and type III do not contain linear curves, the two parameters are estimated using the least-squares technique of non-linear regression. This is also because, in this experiment, prey density was not maintained constant during the exposure period (T: 24 hours). Thus the functional response model employed in this study was a random model (Rogers 1972) with the following equation:

$$
\begin{array}{ll}
H_{a}=H\left\{1-\exp \left[a\left(T_{h} H_{a}-T\right)\right]\right\} & \text { (Type-II) } \\
H_{a}=H\left\{1-\exp \left[\frac{(d+b H)\left(T_{h} H_{a}-T\right)}{(1+c H)}\right]\right\} & \text { (Type-III) }
\end{array}
$$

Where, $\mathrm{b}, \mathrm{c}$, and $\mathrm{d}$ are constant factors that contribute to the instantaneous prey seeking rate (a). Parameter an in the type III functional response model is a function of $\mathrm{H}$ and may be written as follows:

$$
a=\frac{d+b H}{1+c H}
$$

The two regression analyses shown above were performed using data from observations of experimental predatory prey of $S$. aurantiacus on each kind of prey using SAS software version 9.0. The experiment was carried out with seven different prey densities; $2,4,6,8,10,12$, and 14 individuals, with 10 replicates for each density level.

\section{RESULTS AND DISCUSSION}

\section{Sycanus aurantiacus preference on three prey types}

The results of the preference test showed that the average number of $P$. xylostella individuals preyed on by $S$. aurantiacus was significantly higher than that of $C$. pavonana and $T$. molitor. The average number of $P$. xylostella and $C$. pavonana larvae preyed on by $S$. aurantiacus was 6.2 and 3.2, respectively. Interestingly, our results show that $T$. molitor was not selected as prey by $S$. aurantiacus (Figure 2). $S$. aurantiacus prefers $P$. xylostella and C. pavonana as its prey. However, predation of $T$. molitor can occur if a random test is carried out with other prey. These results can be seen in the functional response test in Figure 5.

Preference for prey by natural enemies is caused by the physical and chemical characteristics of prey which can directly affect the level of preference of natural enemies towards their prey (Culshaw-maurer et al. 2020). Other variables, including predation rate, population density, and prey stage, can also help natural enemies select their targets (Martínez et al. 2021). Natural enemies can also use natural mechanisms to determine the fitness of the host or prey (Dindo and Grenier 2014).

The assassin bug, S. aurantiacus, favors soft-bodied prey. This can be observed in $S$. aurantiacus, which likes to prey on $P$. xylostella larvae by sucking them, leaving only the black integument open. Meanwhile, the larvae of $C$. pavonana and T. mollitor that were eaten by $S$. aurantiacus did not have the same experience as the larvae of $P$. xylostella. Another study found that Sycanus falli nymphs and adults preyed more on P. xylostella larvae than Pieris rapae, Spodoptera litura, and Corcyra cephalonica larvae (Truong et al. 2020). Furthermore, predation activity is influenced by the developmental stage of the predator, such as in the first and second instar nymphs of $S$. falli raised with various types of prey (P. rapae, S. litura, P. xylostella, and C. cephalonica) (Sahid et al. 2018).

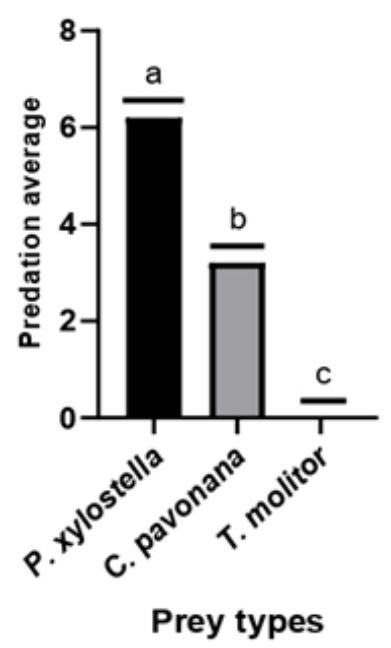

Figure 2. The average individual type of predator preyed on by Sycanus aurantiacus (different letter notation for each type of prey shows significantly different values (Tukey's test: $1 \%$ ) 
Functional response of predator Sycanus aurantiacus to population density of three types of prey

The logistic regression study of the population of $P$. xylostella preyed on by $S$. aurantiacus, and the initial density of the prey revealed that the linear component's coefficient value was negative $(-3.0575)$ and the quadratic component was positive (0.1098). At the 5\% level, the two coefficients are substantially different from zero, with $\mathrm{P}$ values of 0.014 and 0.033 , respectively (Table 1 ).

Table 1 indicates that the density of $P$. xylostella preyed on by $S$. aurantiacus decreased as the initial density of the prey increased. The type-II functional response model is characterized by this pattern of connection between prey proportions and starting density (Figure 3). The predicted values for parameters a and Th were 0.19 and 1.67, respectively, according to non-linear regression analysis. These results show that the instantaneous prey search rate for P. xylostella is about 0.2 individual/hour and that the time required to handle $1 P$. xylostella is 1 hour 40 minutes.

The same type of functional response also occurred to C. pavonana prey, namely type-II (Figure 4). This can be seen from the coefficient value of the linear component, which is negative (-3.5203), and the quadratic component is positive $(0.1327)$. The two coefficients are significantly different from zero but with a smaller significance level, namely a $1 \%$ significance level with P-values of 0.001 and 0.004 , respectively (Table 2). The results of estimating parameters a and Th with the least-squares method of nonlinear regression gave values of 0.20 and 1.91 , respectively. These results indicate that the instantaneous prey search rate for C. pavonana is also constant (density-independent) and almost the same as the instantaneous prey search rate for $P$. xylostella, which is 0.2 individuals/hour.
The handling time for 1 prey against C. pavonana (1 hour 55 minutes) was significantly longer than the handling time for $P$. xylostella prey (1 hour 40 minutes). Furthermore, logistic regression analysis between the percentage of $T$. molitor preyed on by $S$. aurantiacus revealed the coefficient value of the linear component with a negative sign (-1.7167) and the quadratic component with a positive sign (0.0658) (Table 3 ). The results of logistic regression analysis for the predatory functional response model of $S$. aurantiacus to the two prior prey types are likewise shown in our findings, and the functional response curve to T. molitor prey is similarly type-II (Figure 4).

Furthermore, the findings of logistic regression analysis between the percentage of $T$. molitor preyed on by $S$. aurantiacus indicated the coefficient value of the linear component with a negative sign $(-1.7167)$ and the quadratic component with a positive sign (0.0658) (Table 3). Our findings also reveal the results of logistic regression analysis for the predatory functional response model of $S$. aurantiacus to the two prior prey kinds, and the functional response curve to $T$. molitor prey is similarly type-II (Figure 5).

According to da Silva et al. 2020, Euborellia annulipes is very efficient for suppressing $P$. xylostella across a variety of thermal conditions and that predation behavior varies with temperature $25^{\circ} \mathrm{C}$ to $32^{\circ} \mathrm{C}$. The predator Alloeocranum biannulipes Montrouzier and Signoret (Hemiptera: Reduviidae), which was developed as a biological agent against the pest Dinoderus porcellus Lesne, which causes sweet potato chip loss, was studied in laboratory conditions and found to be capable of significantly reducing the number of $D$. porcellus (Loko et al. 2019).

Table 2. The results of logistic regression analysis between the proportion of Crocidolomia pavonana preyed on by Sycanus aurantiacus to its initial density
Table 1. The results of logistic regression between the proportion of Plutella xylostella preyed on by Sycanus aurantiacus and its initial density

\begin{tabular}{|c|c|c|c|c|c|c|c|c|c|}
\hline $\begin{array}{c}\text { Model } \\
\text { component }\end{array}$ & $\begin{array}{c}\text { Estimated } \\
\text { value }\end{array}$ & $\begin{array}{c}\text { Standard } \\
\text { error }\end{array}$ & $\begin{array}{c}\mathrm{Z}- \\
\text { calculation }\end{array}$ & $\begin{array}{c}\text { P- } \\
\text { value }\end{array}$ & $\begin{array}{c}\text { Model } \\
\text { component }\end{array}$ & $\begin{array}{c}\text { Estimated } \\
\text { value }\end{array}$ & $\begin{array}{c}\text { Standard } \\
\text { error }\end{array}$ & $\begin{array}{c}\mathrm{z}- \\
\text { calculation }\end{array}$ & $\begin{array}{c}\text { P- } \\
\text { value }\end{array}$ \\
\hline Constanta & 22.0968 & 7.4211 & 2.98 & 0.003 & Constanta & 23.9662 & 6.5236 & 3.67 & 0.000 \\
\hline Linear & -3.0575 & 1.2431 & -2.46 & 0.014 & Linear & -3.5203 & 1.1007 & -3.20 & 0.001 \\
\hline Quadratic & 0.1098 & 0.0514 & 2.13 & 0.033 & Quadratic & 0.1327 & 0.0458 & 2.89 & 0.004 \\
\hline
\end{tabular}

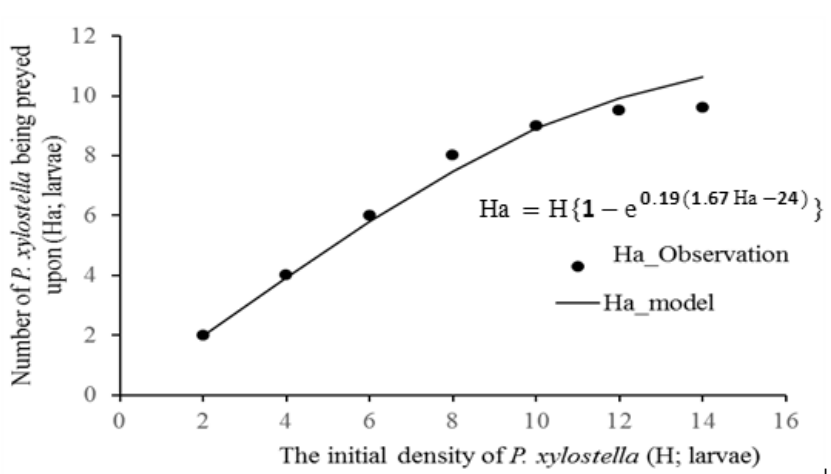

Figure 3. The functional response curve of Sycanus aurantiacus to Plutella xylostella

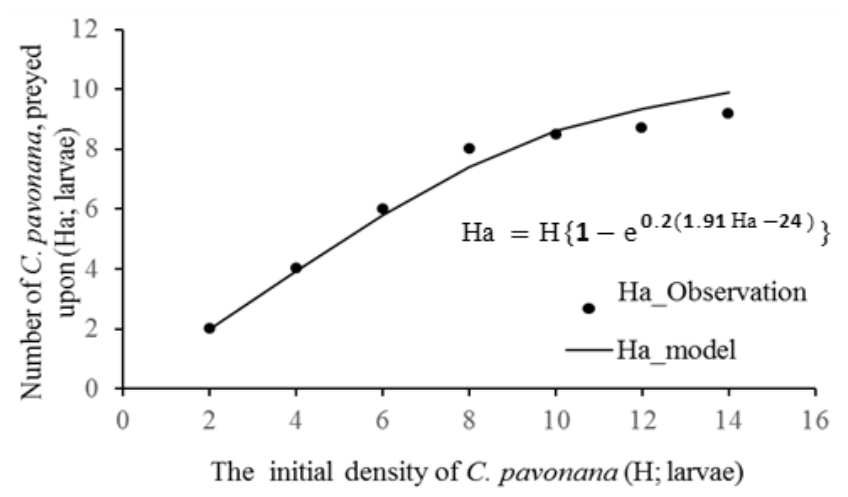

Figure 4. Functional response curve of Sycanus aurantiacus to Crocidolomia pavonana 
Table 3. The results of logistic regression analysis between the proportion of Tenebrio molitor consumed by Sycanus aurantiacus to its initial density

\begin{tabular}{lcccc}
\hline $\begin{array}{c}\text { Model } \\
\text { component }\end{array}$ & $\begin{array}{c}\text { Estimated } \\
\text { value }\end{array}$ & $\begin{array}{c}\text { Standard } \\
\text { error }\end{array}$ & $\begin{array}{c}\text { z- } \\
\text { calculation }\end{array}$ & $\begin{array}{c}\text { P- } \\
\text { value }\end{array}$ \\
\hline Constanta & 11.0556 & 2.1653 & 5.11 & 0.0000 \\
Linear & -1.7167 & 0.4045 & -4.24 & 0.0000 \\
Quadratic & 0.0658 & 0.0184 & 3.58 & 0.0000 \\
\hline
\end{tabular}

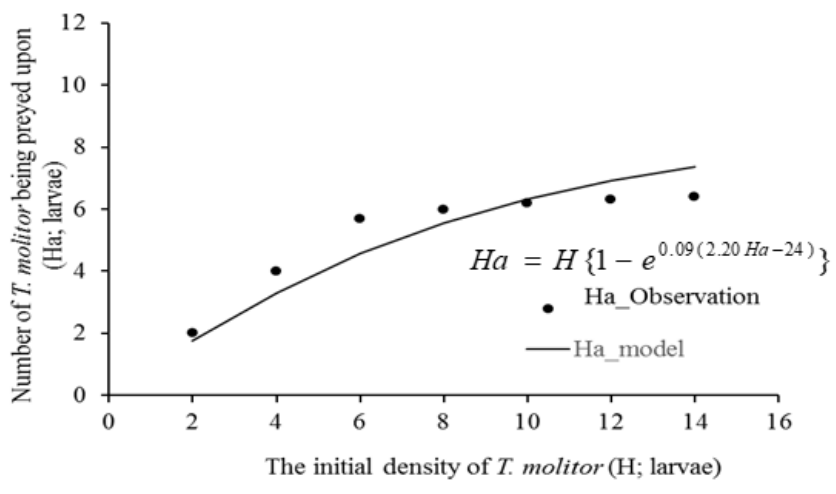

Figure 5. Functional response curve of Sycanus aurantiacus to Tenebrio molitor

Overall, our results show that $S$. aurantiacus prefers $P$. xylostella and $C$. pavonana over $T$. molitor in its predatory preferences. The predator $S$. aurantiacus had the most functional reaction to the three kinds of type-II pests, with the consequences search rate and handling time for $P$. xylostella prey. S. aurantiacus may be investigated further for its potential in the framework of an integrated pest control program, particularly in field-scale cabbage production (Yuliadhi et al. 2015). However, it is critical to consider other types of predators, the development of potential synergistic effects of combination resistant varieties (Loko et al. 2019), as well as insecticidal and repellent plants (Susila et al. 2021) as a package for future development of a more comprehensive integrated pest.

In conclusion, the predator $S$. aurantiacus utilized in this research may be developed for its potential as an environmentally friendly pest control agent for P. xylostella and $C$. pavonana in cabbage commodities. However, further study is required to establish suitable techniques for using $S$. aurantiacus in the field and examine the relationship between these predators and environmental variables such as habitats surrounding cabbage plantations and other kinds of natural enemies found in these crops.

\section{ACKNOWLEDGEMENTS}

The authors would like to express their gratitude to the Head of the Integrated Pest and Management Laboratory (IPMLab), Faculty of Agriculture, Udayana University, Denpasar, Bali, Indonesia, and the Department of Plant
Protection, Faculty of Agriculture, IPB University, Bogor, West Java, Indonesia for their assistance with this study.

\section{REFERENCES}

Ambrose DP, Ganesh KA. 2016. Reduviid predators. In: Omkar (eds). Ecofriendly Pest Management for Food Security. Elsevier, Amsterdam.

Anon. 2020. Cabbage Production in Bali Province by Regency/City (Tons). https://bali.bps.go.id/. [Indonesian]

Berenger JM, Parola P. 2017. Arthropod vectors of medical importance. In: Cohen (eds). Infectious Diseases. Elsevier, Amsterdam.

Bordini I, Ellsworth PC, Naranjo SE, Fournier A. 2021. Novel insecticides and generalist predators support conservation biological control in cotton. Biol Control 154: 104-502. DOI: 10.1016/j.biocontrol.2020.104502.

Chen J, Jin P, Huang S, Guo Y, Tan F, Wang J, Shu Y. 2021. Cabbage cultivars influence transfer and toxicity of cadmium in soil-Chinese flowering cabbage Brassica campestris-cutworm Spodoptera litura larvae. Ecotoxicol Environ Saf 213: 1-12. DOI: 10.1016/j.ecoenv.2021.112076.

Culshaw-maurer M, Sih A, Rosenheim JA. 2020. Bugs scaring bugs: Enemy-risk effects in biological control systems. Ecol Lett 23: 16931714. DOI: 10.1111/ele.13601.

da Silva NG, Truzi CC, Cardoso CP, Vieira NF, Ramalho DG, de Souza JM, De Bortoli SA. 2020. Temperature-dependent functional response of Euborellia annulipes (Dermaptera: Anisolabididae) preying on Plutella xylostella (Lepidoptera: Plutellidae) larvae. J Therm Biol 93: 1-5. DOI: $10.1016 /$ j.jtherbio.2020.102686.

Dindo ML, Grenier S. 2014. Production of Dipteran parasitoids. In: Morales-Ramos JA, Rojas MG, Shapiro-Ilan DI (eds). Mass Production of Beneficial Organisms. Elsevier, Amsterdam.

Dunn RP, Hovel KA. 2020. Predator type influences the frequency of functional responses to prey in marine habitats. Biol Lett 16: 20190758. DOI: 10.1098/rsbl.2019.0758.

Efendi S, Yaherwandi, Nely N. 2016. Study of preference and functional response of Menochilus sexmaculatus and Coccinella transversalis in several different preys. Pros Sem Nas Masy Biodiv Indon 2: 125-131. DOI: $10.13057 / \mathrm{psnmbi} / \mathrm{m} 020201$.

Fathipour Y, Maleknia B. 2016. Mite predators. In: Omkar (eds). Ecofriendly Pest Management for Food Security. Elsevier, Amsterdam.

Hatt S, Lopes T, Boeraeve F, Chen J, Francis F. 2017. Pest regulation and support of natural enemies in agriculture: Experimental evidence of within field wildflower strips. Ecol Eng 98: 240-245. DOI: 10.1016/j.ecoleng.2016.10.080.

Hoa TD, Giang NT. 2019. Development of the cabbage webworm, Hellula undalis (Fabricius) (Lepidoptera: Pyralidae) on different brassica cultivars in Central Vietnam. Res Crop 20: 798-801. DOI: 10.31830/2348-7542.2019.117.

Holling CS. 1959. Some characteristics of simple types of predation and parasitism. Can Entomol 91: 385-398. DOI: 10.4039/Ent91385-7.

Ishikawa T, Toriumi W, Susila IW, Okajima S. 2007. Sycanus aurantiacus (Hemiptera: Heteroptera: Reduviidae), a new harpactorine species from Bali, Indonesia, with brief notes on its Biology. Zootaxa 1615: 21-27. DOI: 10.5281/zenodo.179065.

Jeschke JM, Laforsch C, Diel P, Diller JGP, Horstmann M, Tollrian R. 2021. Predation. In: Elias S (eds). Reference Module in Earth Systems and Environmental Sciences. Elsevier, Amsterdam.

Kim JC, Lee MR, Kim S, Lee SJ, Park SE, Nai Y-S, Lee GS, Shin TY, Kim JS. 2018. Tenebrio molitor-mediated entomopathogenic fungal library construction for pest management. J Asia-Pac Entomol 21: 196-204. DOI: 10.1016/j.aspen.2017.11.018.

Kumarawati NPN, Supartha IW, Yuliadhi KA. 2013. The community of structure and attack of important pests on cabbage (Brassica oleracea L.). E-J Agroekoteknologi Tropika 2 (4): 252-259. DOI: [Indonesian]

Loko YLE, Gavoedo DM, Toffa J, Orobiyi A, Thomas-Odjo A, Tamò M. 2019. Life table of the predator Alloeocranum biannulipes Montrouzier and Signoret (Hemiptera: Reduviidae) and a test of its ability to suppress populations of Dinoderus porcellus Lesne (Coleoptera: Bostrichidae) in stored yam chips. Biol Control 130: 6069. DOI: 10.1016/j.biocontrol.2018.12.011. 
Manly. 1974. A model for certain types of selection experiments. Biometrics 30: 281-294. DOI: 10.2307/2529649.

Martínez LD, de los Angeles MRM, Bueno VHP, Collatz J. 2021. Predation behaviour and prey preference of two neotropical mirids against two key lepidopteran pests in tomato. Intl J Trop Insect Sci. DOI: $10.1007 / \mathrm{s} 42690-021-00605-5$.

Prabaningrum L, Moekasan TK. 2021. Use of light trap for controlling cabbage pests. IOP Conf Ser Earth Environ Sci 752: 012027. DOI 10.1088/1755-1315/752/1/012027.

Poopat P, Maneerat T. 2021. Prey preference and predation efficacy of Sycanus collaris (F.) (Hemiptera: Reduviidae) on Tenebrio molitor (L.) (Coleoptera: Tenebrionidae). Khon Kaen Univ J 49: 1047-1058. DOI: $10.14456 /$ kaj.2021.93.

Rabari GN, Pareek A, Patel BR. 2017. Comparative Biology of Helicoverpa armigera (Hubner) Reared on Different Hosts. Intl J Pure App Biosci 5 (1): 849-856. DOI: 10.18782/2320-7051.2482.

Rameash K, Kumar A, Kalita H, Avasthe RK. 2014. Ecofriendly management of cutworm, Agrotis ipsilon and cabbage butterfly, Pieris brassicae in cabbage. Indian J Plant Protec 42 (4): 349-353.

Rogers D. 1972. Random search and insect population models. J Anim Ecol 18: 1-35. DOI: 10.2307/3474

Sahid A, Natawigena WD, Hersanti H, Sudarjat S. 2018. Laboratory rearing of Sycanus annulicornis (Hemiptera: Reduviidae) on two species of prey: Differences in its biology and efficiency as a predator of the nettle caterpillar pest Setothosea asigna (Lepidoptera: Limacodidae). Eur J Entomol 115: 208-216. DOI: 10.14411/eje.2018.019.

Supartha IW, Yudha IKW, Wiradana PA, Susila, IW. 2020. Response of parasitoids to invasive pest Phenacoccus manihoti Matile-Ferrero (Hemiptera: Pseudococcidae) on cassava crop in Bali, Indonesia. Biodiversitas 21 (10): 4543-4549. DOI: 10.13057/biodiv/d211011.

Susila IW, Supartha IW, Sumiartha IK, Yudha IKW. 2021. Study on the utilization, chemical composition, and insecticidal activity of nutmeg essential oil (Myristrica fragnans Houtt) against fruit flies, Bactrocera spp. (Diptera: Tephritidae). Ecol Environ Conserv 27 151-156.
Truong XL, Pham HP, Thai TNL. 2020. Biology and predatory ability of the reduviid Sycanus falleni Stal. (Heteroptera: Reduviidae: Harpactorinae) fed on four different preys in laboratory conditions. J Asia-Pac Entomol 23 (4): 1188-1193. DOI: 10.1016/j.aspen.2020.09.015.

Uelese A, Ridland PM, Stouthamer R, He Y, Ang G, Zalucki MP, Furlong MJ. 2014. Trichogramma chilonis Ishii: A potential biological control agent of Crocidolomia pavonana in Samoa. Biol Control 73: 31-38. DOI: 10.1016/j.biocontrol.2014.03.011.

Walker AA, Mayhew ML, Jin J, Herzig V, Undheim EAB, Sombke A, Fry BG, Meritt DJ, King GF. 2018. The assassin bug Pristhesancus plagipennis produces two distinct venoms in separate gland lumens. Nat Commun 9 (1): 755. DOI: 10.1038/s41467-018-03091-5.

Xiao Y, Osborne LS, Chen J, McKenzie CL. 2013. Functional responses and prey-stage preferences of a predatory gall midge and two predacious mites with twospotted spider mites, Tetranychus Urticae, as Host. J Insect Sci 13: 1-12. DOI: 10.1673/031.013.0801.

Yuliadhi KA, Supartha IW, Darmiati NN, Bangun A, Yudha IKW, Utama IWEK, Wiradana PA. 2021. Silba adipata (Diptera: Lonchaeidae) parasitoids on cayenne pepper (Capsicum frutescens) in Bali, Indonesia. Biodiversitas 22 (9): 3929-3935. DOI: 10.13057/biodiv/d220939.

Yuliadhi KA, Supartha IW, Wijaya IN. 2015. Characteristic morphology and Biology of Sycanus aurantiacus Ishikawa et Okajima, sp. nov. (Hemiptera Reduviidae) on the Larvae of Tenebrio molitor L. (Coleoptera Tenebrionidae). J Biol Agric Healthc 5 (10): 5-8.

Yuliadhi KA. 2012. Parasitization Rate of Larva Parasitoid, Diadegma semiclausum Hellen (Hymenoptera: Ichneumonidae) on Plutella xylostella (Lepidoptera: Plutellidae) in Candikuning Village, Tabanan Regency, Bali, Indonesia. [Report]. Udayana University, Bali. [Indonesian]

Zhiganov NI, Tereshchenkova VF, Oppert B, Filippova IY, Belyaeva NV, Dunaevsky YE, Belozersky MA, Elpidina EN. 2021. The dataset of predicted trypsin serine peptidases and their inactive homologs in Tenebrio molitor transcriptomes. Data Brief 38: 107301. DOI: 10.1016/j.dib.2021.107301. 